\title{
JOSÉ ARTIGAS
}

IGHLIGHTING the Wars of Independence in Latin
America are the personalities and exploits of the great patriot leaders who took up arms in the cause of freedom. Simón Bolivar and José de San Martín are known throughout the world, for they were outstanding liberators whose efforts were crowned with success. But there were other leaders in the Spanish colonies who are almost equally deserving of fame for their contributions to the revolution, and among such men was José Gervasio Artigas, leader of the rebels in the Banda Oriental. His biography is a story of adherence to ideals and tenacity of purpose in the face of dismaying opposition. Chroniclers of his life, however, are not in agreement as to his possible faults and virtues. As one observer has aptly said, "Perhaps never did the memory of a man meet with more honor in his own country and with less favor without it." 1

\footnotetext{
${ }^{1}$ Koebel, W. H., Uruguay, London, T. Fisher Unwin, 1911, p. 79.

In general, Argentine writers declare him to have been a semi-barbarian, dominated solely by self-interest. See:

Mitre, Bartolomé, Historia de Belgano y de la Independencia Argentina, 3 vols., 3rd Edition, Buenos Aires, Imprenta y Libreria de Mayo de C. Casavalle, 1876-1877.

López, Vincente F., Historia de la República Argentina, 10 vols., Buenos Aires, Juan Roldán y Cia, 1926.

Gandía, Enrique de, Los Treinta y Tres Orientales y la Independencia del Uruguay, Buenos Aires, Espasa-Calpe, 1939.

In contrast, Uruguayan historians tend to make of him a demi-god, a man of no faults. See:

Lasplaces, Alberto, José Artigas, Protector de los Pueblos Libres, Madrid, EspasaCalpe, 1933.

Zorilla de San Martín, Juan, La Epopeya de Artigas, 2 vols., Montevideo, A. Barreiro y Ramos, 1910.

Blanco Acevedo, Pablo, El Federalismo de Artigas y la Independencia Nacional, Montevideo, Impresora Uruguaya, 1939.

Salgado, José, Evolución del Pueblo Uruguayo, Montevideo, Imprenta Nacional, 1941.

Other writers, free of the mandates of nationality and patriotism, find Artigas neither so villainous nor so saintly as he is painted by local biographers. See:

Bealer, Lewis W., "Artigas, the Father of Federalism in La Plata.", in South American Dictators, (A. Curtis Wilgus, ed.), Washington, D. C., The George Washington University Press, 1937.

Martin, Percy Alvin, "Artigas, the Father of Uruguayan Nationality," in The Hispanic American Historical Review, V. XIX, pp. 2-15, Durham, N. C., Duke University Press, 1939.

Koebel, op. cit.
} 
José Artigas was born in Montevideo on June 19, 1764. He was of a leading family in the Banda Oriental, one which traced its American beginnings to the small group of settlers who established the original colony at Montevideo in 1724. His ancestor in this group was his grandfather, Juan Antonio Artigas, formerly an officer in the army of His Catholic Majesty, Philip V. José's father, Martín José Artigas, was also a soldier, in the family tradition, bringing upon himself considerable renown for his service against the Portuguese in the north of the Banda Oriental. His means of livelihood, however, was not the profession of arms, but rather that of ranching, since he possessed two extensive estancias in the Uruguayan countryside. Therefore, José Gervasio was born into a family with strong American traditions, as well as strong military traditions. "Few personalities of the era were more completely American than Artigas." 2

At the time of Artigas' birth, Montevideo was a settlement of some three thousand persons. Among these were five hundred negroes, but very few Indians, inasmuch as the wild Charruas refused to adopt the white man's mode of life. They had retreated to the hinterland, from which they dashed forth to make sporadic raids on the Spanish settlers and their stock. Fighting was still common fare to the colonists, and this atmosphere was to make its mark on the temperament of the young Artigas. ${ }^{3}$

-During his childhood and adolescence, José lived in Montevideo except during the summers, when he worked on his father's ranches at Sauce and Casupá. He was educated in the only school available, the Franciscan convent. It is to be surmised that here he learned a little reading, arithmetic and writing, and much catechism. Little is known of his early life, although one may imagine, using the general character of the country and the time as a guide, that he was interested in the pampa, and more especially in the people who inhabited it, the gauchos." While he worked on his father's estancias, he engaged in occasional skirmishes against Portuguese raiders and smug-

2 Lasplaces, op. cit., pp. 11-12.

8 Ibid., pp. 14-15. For Artigas' early life, see also Barbagelata, Lorenzo, Artigus antes de 1810, Montevideo, Impresora Moderna, 1945.

4 Lasplaces, op. cit., pp. 24-26. 
glers, and earned an enviable reputation as a leader of great prowess and ability. ${ }^{5}$

In 1797, Viceroy Melo organized a company of Blandengues, or lancers, to be stationed at Maldonado, and to run a patrol of the border in order to combat the extensive smuggling activities then going on. Artigas was solicited to join this organization and received a commission as a lieutenant. In the Blandengues he achieved an admirable record, receiving numerous commendations and awards. Twice, however, in 1803 and 1805, he asked to be retired from the service because of illness. Some writers claim it was love that dictated his requests, and this may well be so, for in 1805 he married Rafaela Rosalia Villagrán. The marriage was not a happy one, for just after the birth of their only son, José María, Sra. Artigas became insane and was never completely cured. ${ }^{\circ}$

Despite his requests to be retired, Artigas was still in the Blandengues when Sir Home Popham led the English to the capture of Buenos Aires in June, 1806. The people of the Banda Oriental arose to combat the foreign menace, and fifteenhundred Orientales were among the reconquerors of the capital city. Artigas served as a messenger between Governor Ruíz Huidobro of Montevideo and Santiago de Liniers, leader of the Plata forces. He arrived at Buenos Aires in time to take part in the fighting and, upon his return to Montevideo, was the bearer of the news of victory. In 1807, the English returned, capturing both Maldonado and Montevideo. Still in the Blandengues, Artigas saw action at Maldonado, Buceo, Cardal, and Montevideo. When the British captured the provincial capital, he escaped to the country and led guerrilla groups in harassing actions. The invaders were soon expelled, and Artigas returned once more to border patrol duty.?

In May, 1810, the news that the revolutionary Junta of Seville in Spain had been dissolved by Napoleon's forces stirred the patriots in Buenos Aires to action. They forced Viceroy Cisneros to call a cabildo abierto, and on May 25 under strong patriot pressure, the cabildo created a provisional governing junta of nine members. The junta was to rule in the name of

\footnotetext{
6 Bealer, op cit., p. 37.

6 Lasplaces, op. cit., p. 35.

7 Ibid., pp. 36-40.
} 
the captive Ferdinand VII. ${ }^{8}$ In Montevideo, Governor Elio and the cabildo of that city refused to recognize the junta as a proper governing body, and there arose between the two localities an estrangement which was to reach open warfare in $1811^{\circ}$

Despite the apparent preponderance of loyalist sentiment in the Banda Oriental, there was in fact a powerful force in the area looking toward liberation. Since the end of 1809 , a nucleus of Oriental patriots had been laboring for the independence of Uruguay from Spanish domination. The agents of this plan were Mateo Gallegos in Montevideo and Francisco Javier de Viana in Buenos Aires. At the isolated farm of Dr. Manuel Pérez, such people as Larrañaga, Barreiro, Monterroso, the brothers of José Artigas, Otorgués and other persons assembled to talk about independence. They soon showed that they wanted José Artigas to assume the direction of the movement. ${ }^{10}$

In January, 1811, Francisco Elío, the ex-governor of Montevideo, returned to that city from Spain bearing a commission from the Regency of Cádiz designating him Viceroy of the Río de la Plata. When the junta in Buenos Aires refused to recognize Elio's commission, the Spaniard declared war on the junta. Two days after this declaration, Artigas turned his back on the Blandengues and headed for Buenos Aires, sounding a call to arms as he moved across the Banda Oriental. ${ }^{11}$

Artigas received a warm welcome from the junta in Buenos Aires. His enthusiasm impressed the members of the council, and he was recognized as the foremost leader in the Banda Oriental. They gave him a commission as lieutenant-colonel and placed under his command two companies of patriot troops.

\footnotetext{
${ }^{8}$ Levene, Ricardo, A History of Argentina, (William Spence Robertson, ed. \& transl.), Chapel Hill, University of North Carolina Press, 1937, pp. 218, 227-229.

Mitre, op. cit., I, pp. 239-242.

9 The minutes of the cabildo of Montevideo for this period are reprinted in Maeso, Justo, Los Primeros Patriotas Orientales de 1811, Montevideo, El Laurak Bat, 1888, pp. 53-89.

10 Levene, op. cit., p. 253.

11 Bealer, op. cit., p. 39. Various reasons have been offered, particularly by his detractors, as to why Artigas left the Spanish service so abruptly. Wide credence is given to the story that he engaged in a fierce argument with his commanding officer, who in turn threatened him with imprisonment, giving Artigas cause to flee. Biographers favorable to the Uruguayan occasionally acknowledge the argument but insist that he used it as an excuse to depart, and that he did not flee to escape punishment.
} 
It was hoped that these few soldiers would constitute the nucleus of a large Uruguayan army to be raised by Artigas. An expedition against Montevideo was already being prepared in Buenos Aires when the Banda leader arrived. $\mathrm{He}$ and his handful of men were therefore instructed to proceed to the other side of the river as an advance guard for a larger force soon to follow. They disembarked at Calera de las Huérfanas on April 9, 1811, and the liberation of the Banda Oriental had begun. ${ }^{12}$

While Artigas had been in Buenos Aires making preparations for the invasion, patriots in Uruguay were responding to the call to arms with order and rapidity. On February 28, the "Grito de Asensio" was raised in the West, amid shouts of enthusiasm and much waving of primitive lances. The cry was the signal for the uprising of the entire country, and on all sides small groups of men were seen hurrying to join their leaders, who were, in most cases, the bacendados of greatest prestige. Down from the hinterland of Queguay, Daymán, Río Negro and Santa Lucía, inaccessible to the police, came the gauchos, the lawless ones, eager for battle but without military training and without arms other than those used in their everyday tasks. ${ }^{13}$ In ever-growing numbers, the patriot forces swept rapidly over the country, and by the time Artigas landed in April, nearly the whole province, with the exception of Montevideo, wras in patriot hands.

Within three weeks of his arrival, rebel forces had been victorious in three minor battles: Colla, Paso del Rey, and San José. Driven back to Montevideo by their losses, the Spanish decided on one strong offensive effort, hoping to crush the insurrection with a single blow. The two armies clashed at Las Piedras on May 18, 1811, and after an all-day battle, the patriots, led by Artigas, were victorious. ${ }^{14}$

Who composed the bulk of this rebel army, and why was Artigas their leader? Prominent in the ranks was the gaucho, admirably prepared for battle, inasmuch as his everyday life

\footnotetext{
12Zorrilla de San Martín, op. cit., I, pp. 188-189.

13 Lasplaces, op. cit., pp. 65, 70-71.

14 Zorrilla de San Martín, op. cit., 1, pp. 194-197. See also Maeso, op. cit., pp. 131-146, for Artigas' reports on the battle of Las Piedras to Rondeau and to the junta of Buenos Aires.
} 
was one of constant warfare against nature and his other enemies. He obeyed two organic feelings-disregard for the law and admiration for courage. He could be successfully led only by a chief who symbolized his hopes and desires, a gaucho like himself, who would understand and love him, and in turn be understood and loved. This leader must possess all the gaucho qualities in an heroic degree. In a word, only "the most gaucho among all gauchos" could be the leader of these warriors. Such was Artigas. ${ }^{15}$

His qualifications had broader scope than this, however. Twenty years of travel over his province as a cattleman and an officer in the Blandengues had given him a knowledge of the country and its inhabitants that few of his compatriots could approach. Furthermore, he was not a simple, rural caudillo, capable of attracting to his banner only gauchos and farmers. He was from Montevideo, of an old family, and he had a culture which, though not exceptional, put him above the common level. At the same time that the gauchos, ranchers, Indians, and contrabandists spontaneously gathered about him, so also did the most cultured men of the country-lawyers and priests, who regarded him as an equal. ${ }^{16}$

After their defeat at Las Piedras, the Spanish were forced to forego further offensive action and were compelled to withdraw to Montevideo, where they shut themselves up, relatively secure against attack. The patriot armies were ready to begin the siege, but the Buenos Aires government was undecided as to who should be the commander-in-chief. Belgrano was appointed but never took formal command, as he was called back to Buenos Aires to answer for his recent defeats in Paraguáy. Artigas was regarded as merely a guerrilla leader, with no formal, tactical military training. Therefore, the choice of the junta fell on José Rondeau, a man of good military background, noted for his moderate outlook. The siege was begun on June 1,1811 , with all forces joined and Artigas in the role of leader of cavalry. ${ }^{17}$

Alarmed by his position, Viceroy Elio now began casting about for means of relief. He turned to the Portuguese court

15 Salgado, op. cit., p. 69.

16 Lasplaces, op. cit., p. 63.

17 Pascual, A.D. de, Apuntes para la Historia de la República Oriental del Uruguay, 2 vols., Paris, Imprenta de Bonaventure y Ducessois, 1864, I, pp. 6-7. 
in Rio de Janeiro, and asked the Princess Carlota, wife of the Infante José of Portugal and sister of Ferdinand VII, to recover the Banda Oriental for the House of Bourbon. In Buenos Aires, the government and people were already alarmed by the continual losses experienced by their armies in Upper Peru. When the Portuguese army poured across the Uruguayan border in July, 1811, the Buenos Aires government was therefore quite receptive to Elio's offer of an armistice in exchange for the promised withdrawal of Portuguese forces. It was further agreed that the Buenos Aires army should retire from the siege, and Artigas should withdraw to the Uruguay River. ${ }^{18}$

The so-called "October Treaty" marked the beginning of a split between Artigas, representing the rebels in the Banda Oriental, and Buenos Aires. Until this time, the Uruguayan chief had worked with apparent willingness under the orders of the Porteño junta. Yet the armistice had been made without consulting Artigas, and the harm it did was directed exclusively at the Banda Oriental. Artigas admitted the possible wisdom of a withdrawal of the Buenos Aires forces, but he insisted that the Banda army should be allowed to continue the fight, even if only with "sticks, teeth and fingernails." To his disgust, this idea was rejected. In an apparently conciliatory gesture, the Buenos Aires government designated him supreme commander of Oriental forces and lieutenant-governor of Misiones and Yapeyú. ${ }^{19}$

The withdrawal of the Porteño forces was an easy matter. They simply moved to Colonia, and from there across the river to Buenos Aires. But the evacuation of the Oriental forces presented a far more serious problem. The people of the Banda Oriental had a choice: they could remain in their homes, subject to the whims of the vengeful Viceroy; or they could follow Artigas and his army, leaving behind their homes, farms, and whatever possessions they were unable to carry. They chose the latter course, and thereby came about one of the most stirring mass-movements in history-the exodus of nearly every Uruguayan from his home to whatever site their leader, Artigas, should select as a stopping-place. As the Oriental caudillo moved north and west across his country, there grew behind

18 Lasplaces, op. cit., pp. 73-78.

19 Lasplaces, op. cit. pp. 79-80. 
him a tremendous column, made up of whole families, from the oldest member to the youngest. Carrying their meager possessions in carts or on their backs, these trusting people followed their chief, some riding, many walking, until the entire cavalcade came to a halt and took up its abode along the western shore of the Ayuí River, a tributary of the Uruguay. "The soul of the country went with them." 20

While Artigas was shepherding his flock at Ayuí and making occasional forays against the Portuguese, who had ignored the "October Treaty" and had invaded Misiones, various political changes of importance were taking place. The Regency of Cádiz abolished the Viceroyalty of La Plata, and Elío returned to Spain. He was replaced by Captain-General Vigodet. In Buenos Aires, news of continuing military defeats in Upper Peru led to a change of government. The Junta de Mayo was deposed, and a Triumvirate was established. The Portuguese invasion of Misiones led to sharp words between the Buenos Aires government and Vigodet. This altercation resulted in a declaration by Vigodet that the armistice was broken." Finally, under pressure from Lord Strangford, British Minister at Río de Janeiro, the Portuguese agreed to the Rademaker-Herrera Pact with Buenos Aires. By this Pact, all Portuguese troops were to be withdrawn from the Banda Oriental, i.e., status quo ante bellum. The path was cleared for a renewal of the siege of Montevideo. ${ }^{22}$

The Buenos Aires army, under the command of Manuel Sarratea, moved back into the Banda Oriental and, pending the withdrawal of the Portuguese forces, encamped near Artigas' headquarters. Sarratea immediately began a sefies of raids on the Oriental army, using money and promises of promotion to entice Artigas' best officers and troops into the Porteño organization. He had considerable success, for the months at Ayui had left the Orientales ragged, hungry and discouraged. Naturally, Artigas resented the actions of Sarratea, and this sentiment augmented his growing distrust of Porteños and their policies. The basic issue between Artigas and Sarratea centered in the official relationship between them, i.e., whether Artigas was a subordinate or an ally.

\footnotetext{
20 Ibid., pp. 81-82. See also Zorrilla de San Martin, op. cit., I, pp. 260-270.

21 Lasplaces, op. cit., pp. 86-90.

22 Pascual, op. cit., I, pp. 15-16. The articles of the treaty are reprinted here.
} 
As the armies moved toward Montevideo, Artigas' forces stopped decreasing and began to grow once more. However, his dislike of Sarratea had reached such intensity by this time that the Banda caudillo refused to commit his five thousand men to the siege until the Porteño was removed from his command. ${ }^{23}$ The feud was temporarily settled when Rondeau, speaking for the other officers, wrote a letter to Sarratea in which he urged him to retire and pointed out that only through such a withdrawal could Artigas be persuaded to commit his forces to the siege. ${ }^{24}$ One story, apocryphal perhaps, says that Artigas one night swept through Sarratea's camp, driving all of the commander's horses before him, leaving Sarratea helpless. Whatever the reason may have been, the Porteño retired to Buenos Aires in February, 1813, and command of the army devolved upon Rondeau. ${ }^{25}$

Meanwhile, in October, 1812, the Second Triumvirate called a general constituent assembly, which had its initial session on January 31,1813 , just at the height of the Artigas-Sarratea duel. No deputies were invited from the Banda Oriental, but the assembly instructed Rondeau to secure from the besieging armies an expression of recognition of the assembly's authority. Rondeau in turn passed the request to Artigas, who replied that he would be unable to give an answer until he had consulted the people. To this end, he called a provincial assembly which met at Peñarol, near Montevideo, on April 4, 1813. From this group of Uruguayan leaders were chosen five delegates to the constituent assembly in Buenos Aires. They were given a set of instructions to guide them in making known the objectives of the people of the Banda Oriental. ${ }^{26}$

Largely the work of Artigas, the articles of which this document was composed were to become famous as the "Instructions of the Year XIII." They constituted a crystallization of the political ideology of Artigas, and they remained his principles throughout his career.

On several counts, the instructions not only constitute a landmark in Uruguayan history but also have left their imprint on the constitutional development of all the Platine republics. For the first

\footnotetext{
23 Lasplaces, op. cit., pp. 90-93.

24 A copy of the letter appears in Pasrial, op. cit.- I. p. 21.

25 Bealer, op. cit., + in

$26 \mathrm{Ibid}$. $\cap 42$
} 
time in their history, the three fundamental principles of the revoIution were clearly and explicitly formulated; absolute independence of the colonies ( hitherto the fiction of loyalty to Ferdinand VII had been assiduously maintained); a republican form of government; autonomy of the confederated provinces. The first of these principles was not adopted by the Argentine provinces until the Congress of Tucumán in 1816; the second was for many years more honored in the breach than in the observance; the third came to be the basis of the Argentine Federal Constitution of 1853 after forty years of internal struggle. ${ }^{27}$

In addition to these three provisions, the Instructions called for full civil and religious liberty, a three-way division of the government, and the removal of the capital to some place other than Buenos Aires. Carrying these guides, the five delegates proceeded to the capital to take their seats in the assembly. It was at this point that the Porteño authorities made one of their most impolitic moves-they refused to seat the deputies from the Banda Oriental for the reason that they had been irregularly elected. In reality, the action of the assembly was a manifestation of the determination of the Unitarists to prevent the Federalists from spreading their propaganda. ${ }^{28}$

Artigas was stunned, and then resentful. He offered to hold new elections, but the Buenos Aires authorities directed instead that Rondeau should be in charge and that there should be elected three deputies to the Constituent Assembly and three persons to run the government in the Banda Oriental. Artigas cooperated with Rondeau until it was revealed that the provincial assembly was to be held at the Capilla Maciel in Miguelete near Buenos Aires, rather than at Peñarol. His protests, however, were in vain.

The Oriental Assembly, duly elected, was inaugurated on December 8, 1813, completely under Porteño control. It annulled everything done by its predecessor, selected three members of a governing junta which never governed, and chose three deputies to the Constituent Assembly who were never admitted despite their non-Artigas character. The Banda Oriental was the only province not represented in the Constituent Assembly. Obviously, the Uruguayans resented this treatment, while other rural provinces tended to look askance at such procedures. ${ }^{29}$

27 Martin, op. cit., p. 8.

28 Bealer, op. cit., p. 42.

29 Lasplaces, op. cit., pp. 119-120. 
As Lasplaces says, "this was the drop which filled the glass," and Artigas was nearly forced to rebel against the Porteño government. His insurrection did not take the form of hostilities, however. . During the night of January 20,1814, Artigas and all his forces broke camp and moved away to the West, leaving the siege in the hands of Rondeau and his followers. Vigodet, upon the occasion of Artigas' duel with Sarratea, had made offers of money, promotion and honors to the Oriental caudillo, but he had been turned down. Now he repeated his offers, and once more Artigas was not interested. Said the Banda leader, "With the Porteños I will always have time to compromise; with the Spaniards, never. ${ }^{30}$

Instability was fast becoming the major characteristic of Buenos Aires government. The Triumvirate had replaced the Junta and in turn was replaced by the Supreme Director. There seemed to be complete disorientation, and each loss to the Spanish or each new political insurrection meant a change in government. The Constituent Assembly had produced little, and after the defeats of Belgrano at Vilcapugio and Ayohuma, it was deemed best to put all controls in the hands of one man. The first Supreme Director was Gervasio de Posadas, who took office late in January, $1814 .^{31}$

One of his initial acts was to issue a decree against Artigas for leaving the siege of Montevideo. He declared the Uruguayan to be infamous, an outlaw, deprived of his rank and a traitor to his country. Posadas continued by instructing that the Oriental leader was to be pursued and taken, offering six thousand pesos for him, dead or alive. Amnesty was proffered to those of Artigas' followers who would give themselves up within a specified period, but warning was given that those who persisted in their obstinancy would be declared traitors and, if caught, would be shot within twenty-four hours of their capture. $^{32}$ Artigas' reaction to this pronouncement can be imagined.

His withdrawal from the siege had signalled a complete break with the Buenos Aires oligarchy, and further, it meant the commencement of three-cornered warfare among the

${ }^{30}$ lbid., pp. 120-121.

31 lbid.

32 Zorrilla de San Martin, op. cit., I, p. 429. 
Spanish, the Porteños, and the Uruguayans. Up to this point, Artigas had in general worked under or with the Buenos Aires authorities. Although his activities had been confined to his own country, he had done nothing but collaborate in the Porteño plans to break the power of Spain. Now, for the first time, he became a true rebel against an alleged central and popular government. Apparently his plan was to arouse all the provinces bordering on the Banda Oriental and induce them to join him in a federal league.

One may ask what his objectives were in this campaign of insurrection and confederation. There is nothing to indicate that he desired to replace the Buenos Aires government with himself Nor does it seem apparent that his desire was to dominate all the other provinces, inasmuch as he was not received in these new areas with fear, but rather with acclaim. $\mathrm{He}$ was even given a new title, "Protector of Free Peoples." It is argued, and perhaps logically, that he found it necessary to fight for his ideals by the only method left to him-that of force. In his eyes, the Buenos Aires government was composed of a monarchistic, unitaristic oligarchy, and to him the situation admitted of two possible solutions: submission or rebellion. His life and character indicate his inability to submit passively to something he felt was wrong. Therefore he must rebel.

Nevertheless, he did not turn on his former allies until he had made many efforts to compromise, within honorable limits, keeping intact the dignity and interests of the country of which he had been chosen civil and military head. But the combination of the "October Treaty", the Sarratea intrigyes, the rejection of his delegates to the Constituent Assembly, and the obvious monarchical tendencies of the Plata authorities drove him to seek allies in the federal cause. Posadas' decree which declared Artigas an outlaw served only to make the situation more bitter, and from that day forward there was never again true peace between the caudillo and the Central Government. $^{\text {33 }}$

Artigas and his followers left the siege of Montevideo in January, 1814. In June of the same year, Vigodet surrendered the city to the Porteño forces. The capitulation was accepted by Carlos Alvear, who had taken command of the army just

33 Lasplaces, op. cit., pp. 125-129. 
in time to make a triumphant entry into the provincial capital. In the name of the Buenos Aires government, which was headed by his uncle, Supreme Director Posadas, Alvear established a despotic regime which ignored the sovereignty and other rights of the natives. The Montevideans rightly characterized the two dominations, Spanish and Porteño, when they said, "the last day of despotism and the first day of the same." 34 Otorgués, one of Artigas' lieutenants, immediately demanded that the city be turned over to him, but he was completely outmaneuvered by Alvear and was not able to accomplish his objective until Artigas' successes in the North and West made it imperative for the Porteños to evacuate the city in January, $181 .^{85}$

The withdrawal of the Spanish forces from Montevideo marked the end of the first phase in the battle for Uruguayan independence. Enemy No. 1 was gone. Now began the second campaign, that against Buenos Aires. Zorrilla de San Martín has labeled it variously "The Second Independence" and "The Guayabos Campaign." 38 Artigas established his headquarters in the North, on the shore of the Uruguay River. His lieutenants were scattered about the Banda Oriental, with Rivera and Lavalleja in the center, Otorgués in the South near Montevideo, and Godea in the West along the Uruguay. On the western side of the river, in Entre Ríos and Corrientes, his caudillo allies were Ramirez and Blas Basualdo. The campaign was one of marches, counter-marches, and surprise attacks. It was climaxed by the complete rout of Dorrego's Porteño forces at Guayabos by the Oriental army under Rivera on January $10,1815 .^{87}$

Corrientes and Entre Ríos had been fostering federal plans for some time, and were the first to ally themselves with Artigas. After the defeat of Porteño Colonel Holemberg at Espinillo by federalist forces in April 1814, Posadas sent two representatives from Santa $\mathrm{Fe}$ to Artigas' headquarters in an effort at mediation. These men, Dominican Friar Mariano Amaro and Francisco Antonio Candioti, met with the caudillo at Belén. Artigas proposed the following: that the Director

34 Salgado, op cit., p. 77.

35 Zorrilla de San Martin, op. cit., I, pp. 325-329.

36 Ibid., p. 329-342.

37 Ibid. 
repeal the infamous decree against him; that the people of Entre Ríos, Corrientes and the Banda Oriental, who had been declared free under the protection of the Chief of the Orientals, suffer no further molestation; that the independence just indicated did not mean a necessary separation of provinces which would prevent common action in the revolution. Amaro and Candioti must have considered this an equitable proposal, for they signed a convention with Artigas on these bases, ad referendum the Director. Posadas refused confirmation.

When the negotiations were concluded, the mediators, plus Colonel Holemberg and all the prisoners taken at Espinillo were returned to Santa $\mathrm{Fe}$, and thence to Buenos Aires. That they were impressed by Artigas' personality is indicated by Posadas himself, when he wrote that they all arrived in Buenos Aires saying, "the cause of Artigas is just." Apparently the recent mediators became firm federal agents, for upon their return to Santa $\mathrm{Fe}$ the Porteño governor of that province complained that they were reviving to a frightening extent the pro-Artigas sentiment, which had only recently been calmed down. ${ }^{38}$

Supreme Director Posadas fell from power in January, 1815, largely as a result of the Porteño defeat at Guayabos and dissent in the Army of the Andes. He was succeeded by his nephew, Carlos de Alvear, unitarist, monarchist, Anglophile, opportunist, and egotist. Shortly after this remarkable man became Dircctor, Artigas crossed the Paraná, entered the city of Santa $\mathrm{Fe}$ and deposed the Porteño govern's, Díaz Vélez. The inhabitants of the province then elected Francisco Candioti as governor. ${ }^{39}$ Alvear left Buenos Aires for Santa $\mathrm{Fe}$ at the head of part of the army, but upon arriving at Fontezuelas, his troops mutinied under the leadership of Colonel Ignacio Âlvarez Thomás. Shortly after this, an uprising took place in Buenos Aires, and Alvear was forced to flee. The revolt was backed both by Rondeau in Upper Peru and San Martín in Mendoza. ${ }^{40}$

Álvarez Thomás became the new Supreme Director after Rondeau, the original choice, indicated his desire to stay with the army. Artigas had encouraged the revolt, and apparently

38 Lasplaces, op. cit., pp. 128-130.

39 Ibid., pp. 144-145.

40 Ibid., p. 146. Levene, op. cit., p. 291. 
there was once more harmony between the two governments. Álvarez Thomás went so far as to send to Artigas seven former Alvear-supporters in chains. Contrary to expectations, the Banda leader set them free and returned them to Buenos Aires with the message, "General Artigas is not a hangman." was not the ultimate exchange of personnel between the two leaders, however.

Álvarez Thomás sent two commissioners, Blas José de Pico and Dr. Bruno de Rivarola, to meet Artigas at his headquarters in Hervidero. Out of their conferences came a reaffirmation of the principles and objectives of the Oriental chief, this time more specifically stated than in the famous Instructions. Artigas asked the following: that the Act of Congress of April 5,1813 , be recognized, i.e., that the Banda Oriental form a part of a state to be called the United Provinces of the Río de la Plata; that all provinces join in a defensive and offensive alliance; that all provinces have equal rights and privileges, and each renounce the policy of subjugating the others; that the Banda Oriental retain its full liberty and rights, but be subordinate to a federal constitution to be created by a General Congress. In reply, Buenos Aires offered to recognize the independence of the Banda Oriental and to renounce the rights she possessed during the preceding regime. ${ }^{42}$

The negotiations produced no result, and the commissioners returned to Buenos Aires blaming Artigas for the failure of their mission. The caudillo was determined to try again, however, and to this end he called a Congress at Concepción del Uruguay in Entre Ríos on June 23, 1815. The Congress selected and sent four delegates to Buenos Aires, where they renewed negotiations. Failure attended their efforts. They were arrested, and the Directory made preparations to reconquer Santa Fe. General Viamont invaded the province just as Governor Candioti died. He had some early successes, but was ultimately defeated and captured. As he had done previously, Artigas sent the leader and all prisoners back to Buenos Aires. ${ }^{43}$

11 Bealer, op. cit., p. 45.

42 Lasplaces, op. cit., pp. 148-149.

43 Ibid., pp. 154-155. For the opinion of an United States agent concerning the Artigas commission, see Manning, Diplomatic Correspondence of the United States Concerning the Independence of the Latin American Nations, 3 vols., New York, Oxford University Press, 1925, 1, pp. 340-341, Doc. 205. 
The successful conclusion of the Santa Fe campaign saw Artigas at the height of his power. He was acknowledged as the Protector over 350,000 square miles of Plata territory, stretching from Córdoba to the sea. In the Banda, with the title "Chief of the Orientals," he was about to undertake a program of internal rehabilitation and development. The loose federal league of which he was head gave him control over Santa Fe, Entre Ríos, Corrientes and part of Misiones, with the title "Protector of Free Peoples." Paraguay was in accord with him and Córdoba was loosely allied. ${ }^{44}$ The arrangement comprised a significant pattern, for it revealed a basic division, with the agricultural and pastoral people of the rural areas opposed to the commercial class of the urban centers. The gauchos, inherently democratic and anti-centralist, were strong in favor of localism and therefore supported their own Artigas. ${ }^{45}$

What was he like at this time, this contradictory supergaucho and man of poise and polish? Father Larrañaga has left us a description of him.

In no way did he appear a general. His clothing was that of a civilian and very simple; his pantaloons and a blue jacket with neither lapels nor cuffs, shoes and white stockings, and a cape made of very heavy cloth, these were his best, and even they were poor and threadbare. $\mathrm{He}$ is a robust man of regular stature, of light complexion, of very good appearance, with an aquiline nose, black hair with few gray hairs; he appears to be forty-eight years of age; his conversation is attractive; he speaks quietly and deliberately. It is not easy to confound him with long reasonings, for he reduces the difficulty to a few words, and, full of many experiences, has foresight and an extraordinary ability to hit the mark; he knows the human heart very well, especially that of our countrymen, and therefore there is no one who can equal him in the art of controlling them. All surround him and all follow him with love, even though they. live naked and full of misery at his side, not through lack of resources, but rather in order not to press the people with contributions; he would prefer giving up the command to seeing that his orders were not carried out in this region ...

Our sessions lasted until suppertime. This meal was in keeping with the tone and manner of our general: a bit of roasted beef, soup, stewed meat, plain bread, and wine served in a cup for lack of glasses; four plated iron spoons, with no knifes or forks save those each man brought with him; two or three porcelain plates, a pewter plat-

\footnotetext{
44 Bealer, op. cit., p. 46. For telations with Córdoba at this time see Garzón, Ignacio, Crónica de Córdoba, 3 vols., La Minerva, 1898-1902, I, p. 222 ff.

45 Bealer, op. cit., p. 46.
} 
ter whose borders were loose; three chairs and a chest served as seats, the rest remained on their feet. Thus may be seen of what our table service consisted, with tablecloths of Misiones cotton, but without napkins, but even as I have learned, much of this was borrowed. After finishing dinner, we went to sleep, and the general gave me not only his leather cot, but also his room, and he himself retired to a ranch. He would not listen to my excuses, but strongly pooh-poohing me, would not give in.

Very early .... we had the general in the house; he surprized us while we were yet in bed; we rose immediately; I said mass; then came breakfast, but this had neither tea nor coffee nor milk nor eggs. Nor was there mate, but a gloriado, which is a sort of punch, very hot, with two beaten eggs which they had found with difficulty . . . There was nothing else to do but accustom ourselves to this 'Spartanism. ${ }^{46}$

The year 1815 constituted the only peaceful period Artigas experienced during his career as caudillo of the Banda Oriental, and even this was relative. He had two major aims. In the first place, he meant to safeguard the protected provinces in accordance with his Instructions of the Year XIII, which brought him into conflict with Buenos Aires. In the second place, he aimed at the rehabilitation of his own country, and this objective was hampered in turn by the conflict mentioned above. To control the area, he found it necessary to stay in the West, since Montevideo was improperly located with respect both to strategy and the jealousy of rural people toward the city. ${ }^{47} \mathrm{He}$ established his capital at Hervidero, on the Uruguay River. Here also was located a concentration camp for Spaniards and other supporters of the old regime. The camp bore the euphemistic name of Purificación. It was not precisely a prison, for its inmates were allowed a certain degree of freedom, cultivating the soil and even sending their children to a primary school run by Fray José Benito Lamas. ${ }^{48}$

Here in his capital, between battles, diplomatic negotiations and congresses, Artigas tried to restore the Banda Oriental. The country was slowly reviving, for the people were returning to their homes, and trade and commerce were coming back. The caudillo reorganized the fiscal system on a more efficient basis, distributed lands to those who would work them, regulated the slaughter of cattle, revitalized deserted areas by settling civil-

\footnotetext{
46 Bealer, op. cit., p. 47.

47 Ibid.

48 Lasplaces, op. cit., p. 151.
} 
ized Indians there, and founded new towns. The country was divided into six administrative departments, each headed by a cabildo. They were: Montevideo, Maldonado, Soriano, Canelones, San José, and Colonia. Efforts were made to aid industry and commerce, and the judicial system was reorganized. A national merchant marine was created, and the flag of Uruguay was found even in European and North American ports. There were primary schools in Montevideo and Purificación, and a library in the former city. It is apparent that Artigas did much in this year of quasi-peace to rehabilitate a country that was depopulated, ravaged by warfare, and semi-primitive in atmosphere. ${ }^{49}$

In Montevideo, the caudillo demonstrated his regard for the principle of self-government by the type of administration he encouraged there. Otorgues, who moved in immediately after the Porteños evacuated the seaport, left much to be desired as an administrator. Artigas recalled him, and sent as his replacement his former secretary, Miguel Barreiro. Fructuoso Rivera accompanied Barreiro as head of the military garrison. When the governor arrived in Montevideo, he found the new cabildo already elected and functioning. This body was composed of persons who had been chosen by the members of all other cabildos in the country, and was a sort of central cabildo. It was to join with Artigas' representative in running the Banda Oriental.

In a letter from Artigas to Barreiro, the caudillo said, "And although I have full confidence in your honor and rectitude, believing as I do that you will carry out the measures of government with all that moderation which should exist in 'the character of a public functionary, nevertheless, I must recommend very strongly that you pay special care and attention to putting in practice all those guarantees necessary to reviving and assuring the public confidence; that private rights are respected and that no one is molested or persecuted for his private opinion, provided that those who profess ideas different from ours do not intend to disturb the peace and involve us in new revolutions."

When one considers the paucity of resources with which Artigas had to work, one is amazed at his optimism and the

4: Ibid., pp. 156-158.

50 Lasplaces, op. cit., pp. 137-139. 
results he achieved. That he lacked most of the trappings and aids usually available to a man of his position is revealed in a letter written by the traveler, J. P. Robertson. Said he,

I came to the Protector's headquarters at the so-called town of Purificación. And there (I pray, you do not turn skeptic on my hands) what do you think I saw? Why, the most excellent Protector of half the New World (!), seated on a bullock's skull, at a fire kindled on the mud floor of his hut, eating beef off a spit, and drinking gin out of a cow horn! He was surrounded by a dozen officers in weather-beaten attire, in similar positions, and similarly occupied, with their chief. All were smoking, all gabbling. The Protector was dictating to two secretaries, who occupied, at one deal table, the only two dilapidated rush-bottom chairs in the hovel. To complete the singular incongruity of the scene, the floor of the one apartment of the mud hut (to be sure, it was a pretty large one) in which the general, his staff, and secretaries, were assembled, was strewn with pompous envelopes from all the Provinces (some of them distant 1,500 miles from the center of operations) addressed to "His Excellency the Protector." At the door stood the reeking horses of couriers arriving every half-hour, and the fresh ones of those departing as often. Soldiers, aide-de-camp, scouts, came galloping in from all quarters, all was referred to "His Excellency, the Protector"; and his excellency the protector, seated on his bullock's skull, smoking, eating, drinking, talking, dispatched in rapid succession the various matters brought under his notice, with that calm, or deliberate but intermitted nonchalance, which brought most particularly home to me the truth of the axiom, "Stop a little that we may get on the faster" . . . He received me, not only with cordiality, but with what surprized me more, comparatively gentlemanlike manners, and really good breeding . . . The Protector's business was prolonged from morning till evening, and so were his meals; for, as one courier arrived another was dispatched, and as one officer rose up from the fire at which the meat was spitted another took his place.

Robertson had come to ask reparation for damages he had suffered in Corrientes and was therefore able to give an account of Artigas' financial difficulties and the state of his treasury. When he had submitted his claims, Artigas, far from being angry, merely smiled.

"You see," said the general with great candour and nonchalance, "how we live here; and it is as much as we can do, in these hard times, to compass beef, aguardiente, and cigars. To pay you 6,000 dollars just now is as much beyond my power as it would be to pay you 60,000 or $600,000 . "$ "Look here," said he; and so saying, he lifted up the lid of an old military chest, and pointed to a canvas. bag at the bottom of it. "There," he continued, "is my whole stock 
of cash; it amounts to 300 dollars; and where the next supply is to come from I am as little aware as you are." 51

The year 1815 marked the peak of Artigas' power and the sole interval in which he had opportunity to undertake measures of restoration and rehabilitation. Had he had more time, he might have accomplished much, but the peace was ephemeral, and 1816 saw the beginning, not only of a new war, but also that of a decline in the great leader's power. Furthermore, his inability to combat successfully the Portuguese, who were to invade Uruguay once more in 1816, was occasioned in no small degree by the renewed efforts of the Buenos Aires government to separate from him those members of his federal league who were outside the Banda Oriental.

While Artigas was making efforts at restoring his country, events in Buenos Aires had moved with typical rapidity. Late in 1815, Rondeau was badly beaten by the royalists at Sipe Sipe in Upper Peru. This defeat brought about the customary clamor for a governmental shake-up. The Constituent Assembly of 1813 had produced no definite results, and ever since its dissolution there had been demands for a new assembly. In March, 1816, a new congress convened at Tucumán. All provinces were invited, but only two-thirds were represented. Of Artigas' group only Córdoba sent a delegate, and Paraguay also stayed away. In return for adherence to the Congress, Artigas demanded public ratification of a treaty affirming the integrity of Santa $\mathrm{Fe}$, and other guarantees of federalism. Predominantly Unitarist, and, to some degree, monarchist, the Congress refused his demand. The greatest act of the body was the Declaration of Independence, issued on July 9, 1816, slightly over three years later than that of Artigas. ${ }^{52}$

On his other border, the Banda leader was faced with an imminent invasion by the Portuguese. The motives of the Lusitanians seem clear. Ostensibly, anarchic conditions in the Banda Oriental made necessary an occupation by Portuguese troops in order to restore law and order and to make Brazilian borders safe from continued raids and skirmishes. In reality, the invasion was another manifestation of the Portuguese desire to own Uruguay. Expelled in 1777, held back by the British in 1812, the Lusitanians now saw the way clear to get what

51 Bealer, op. cit., pp. 48-49.

b2-Bealer, op. cit., p. 51. 
they wanted. Their chances of success were bolstered by the availability of some fifteen thousand veterans of the Napoleonic Wars. ${ }^{53}$

It seems not unlikely that the Porteño government was partially responsible for the Portuguese action, although it may well have been through lack of any action on the part of Buenos Aires rather than through some positive effort. Still, it is known that José M. García, originally sent to Río de Janeiro by Alvear, remained in that city during the governments of Álvarez Thomás, Balcarce and Pueyrredón, apparently as their official agent. When he was disappointed in his plan to have England assume sovereignty over La Plata, García allegedly turned to negotiating for Portuguese action in this same direction. In any case, the Buenos Aires authorities made no practical efforts to halt the Portuguese conquest. ${ }^{54}$

On June 22, 1816, the Montevideo cabildo issued a call to arms. Artigas, at Purificación, sent this plea to all the communities within his federal league, asking their governors to aid in resisting the Portuguese. Not much help was available, however, for the leaders in the outer provinces needed all their forces to fight the Buenos Aires Unitarists, once more active in their efforts at reconquest. Artigas even suffered from losses which were self-inflicted, for in August he renounced his use of some Corrientes soldiers, saying,

Yesterday I wrote the governor and commander-in-chief of the troops of that province, Juan Bautista Méndez, that he should retire with all his troops. I have noticed the displeasure with which they march, and in my columns I do not want men who fear danger. The men whom I have the honor of commanding fight for their liberty and make their sacrifices in order to assure the interests of these provinces. Consequently, the men who follow me must be volunteers, and any operation not a part of this principle is disagreeable to me. ${ }^{55}$

As opposition to the Portuguese invaders, therefore, Artigas had only a few detachments from Entre Ríos and those forces he could recruit in the Banda Oriental. The Indians of the Misiones Orientales, always loyal to the caudillo, joined him; but despite their bravery, they were neither properly armed nor trained. They were led by a chief named Andrés Artigas, or Andresito. ${ }^{\text {56 }}$

53 Zorrilla de San Martín, op. cit., II, p. 24.

54 Ibid., II, pp. 29-31.

55 Lasplaces, op. cit., pp. 175-176.

56 Ibid. 
In a council of war at Porto Alegre on September 20, 1816, the Portuguese decided that General Lecor, with a large force, was to move along the shore of the Atlantic and La Plata. Flanked by a naval squadron, he was to take Montevideo, Maldonado and Colonia, thus cutting off Artigas from the river and the sea. The rest of the Lusitanian forces were to be split in two and were to invade at designated places along the Banda Oriental border. ${ }^{57}$

Artigas realized that with his six thousand poorly armed gauchos and Indians spread thinly over the countryside, he had little chance of stopping twelve thousand Portuguese veterans. $\mathrm{His}$ solution was to fight invasion with invasion. While Lecor was moving along the coast, three of Artigas' lieutenants, Andresito, Verdun from Entre Ríos, and Sotelo from Corrientes, invaded the Misiones Orientales, which had been in Portuguese hands since early 1811. It was a good plan. Early successes raised Uruguayan hopes, but all three lieutenants were finally defeated and forced to retreat to the Banda Oriental.

In October, 1816, Artigas himself was badly beaten at Corumbe. The Orientals were having no better luck in other parts of the country. In the South, Otorgués was defeated several times by Marshal Silveira. Fructuoso Rivera and his army were nearly destroyed in November at the bloody battle of India Muerta by Lecor. Within a few months, the Oriental forces were badly chopped up. The tactics, armament, and discipline of the Portuguese were too much for the willing but untrained Uruguayans. It did not mean, however, that Artigas was finished. ${ }^{58}$

The early losses suffered by the Oriental army disheartened the patriots of Montevideo. Although the city was fortified, there were no cannon or arms of other kinds, since they had all been removed by Alvear in 1815. Furthermore, there was no trained army to defend the city, but rather only a single battalion of civilian volunteers. It was recognized that they could offer but little resistance to the six thousand well-armed Portuguese veterans under Lecor. In these circumstances, the Montevideo cabildo sent a delegation to Buenos Aires to ask for help. Pueyrredón, who had thus far made a single weak pro-

57 Zorrilla de San Martin, op. cit., II, p. 48.

68 Lasplaces, op. cit., pp. 178-179. 
test against the Lusitanian invasion, stipulated that in exchange for the aid sought by the Orientals, Uruguay must swear allegiance to the United Provinces and become a part of the nation. The cabildo refused to accede to his proposal. ${ }^{58}$

While these negotiations were going on, Artigas was fighting the Portuguese along the borders of the Banda Oriental. Apparently it never occurred to him to turn to Pueyrredón for aid. On the contrary, the caudillo had closed the doors of Uruguay to Porteño ships, and had created a flotilla under the Irish mariner, Campbell, who was operating on the upper Uruguay River, fighting both the Directory and the Portuguese., When Artigas heard of the intercourse between Montevideo and Pueyrredón, he made clear his stand on the matter in a letter to the cabildo. Said he,

The Chief of the Orientals has always indicated that he loves his country too much to sacrifice this rich patrimony at the low price of necessity. Fortunately, the present situation is not so extreme that we must tie ourselves to such a compromise. Please repeat this in my name to that government, and assure him of the paucity of my regard for the liberality of his ideas and the niggardliness of his sentiments. ${ }^{60}$

In the light of Montevideo's relative defenselessness, Lecor was able to take the city without opposition on January 20, 1817. Director Pueyrredón dispatched various notes protesting this invasion of an "Argentine province." Río de Janeiro replied that if the Banda Oriental was one of the United Provinces, the government of Buenos Aires should have taken steps to prevent the invasions which Artigas and his guerrillas were making into Brazil. Inasmuch as neither Pueyrredón nor the Porteño army assumed an energetic attitude in the matter, the Portuguese remained in possession of the lower east bank of the Uruguay. ${ }^{81}$

The beginning of the war against the Portuguese signalled also a renewal of the struggle between Federalists and Unitarists in the Artigas provinces outside the Banda Oriental. Artigas made an official declaration of war against the Buenos Aires government and Pueyrredón late in 1817, accusing them of favoring Portugal and aiding the enemy with supplies. In

59 Lasplaces, op. cit., pp. 179-184.

60 Ibid., pp. 181-182.

61 Levene, op. cit., pp. 330-331. 
typical Latin manner, observing the amenities even while calling names, the Oriental caudillo wrote,

Your Excellency is a criminal worthy of no consideration ... I speak for the present and I speak for always: Your Excellency is responsible before the altar of the nation for your inaction and your malice toward the common interest.

Thinking he could now reconquer the other federal provinces which he had always refused to recognize, Pueyrredón sent armies into Corrientes, Entre Ríos, and Santa Fe. His successes were few and ephemeral. He did manage to get one caudillo of Entre Ríos, Hereñú, to rebel against Artigas, but Francisco Ramírez, another leader in the same province, put the rebel and his Buenos Aires aides to rout. Santa $\mathrm{Fe}$ was invaded by Viamont and Díaz Vélez, but both were defeated. These actions did have the effect of preventing the provinces from aiding Artigas, however. ${ }^{62}$

But the Chief of the Orientals fought on. Defeated in his first series of engagements with the invaders, he regrouped his battered forces and sent them on another invasion of Misiones, this time under Andrés Latorre. On January 4, 1817, at the Battle of Catalán, the bloodiest of the war, the Uruguayans were beaten and left a thousand men dead on the field. At the same time Artigas was defeated at Arapey, and Andresito lost at Aguapey. Keeping an eye on Lecor, Rivera was forced to retreat to Colonia. This stronghold fell later in the year and yielded as captives the Colonels Manuel and Ignacio Oribe, and Rufino Bauzá.

Artigas' forces were thus reduced to small guerrilla groups, and the caudillo himself, whose capture would have mean't the end of resistance, moved about the countryside like a wraith, just out of reach of the pursuing Portuguese. But his misfortune continued. In 1818, Otorgués, Lavalleja, Bernabé Rivera, and Manuel Francisco Artigas were all taken prisoner. In 1819, Andresito was taken in battle and later died in prison in Río de Janeiro. Little by little, the gallant leader was deprived of his support, but he lost none of his fire. When Lecor offered him a position as a colonel in the Portuguese army, a home in Río de Janeiro and full honors, Artigas replied, "Tell your master that when I lack men with which to fight his henchmen, I will fight them with wild dogs."

62 Lasplaces, op. cit., pp. 192-193.

63 Ibid., pp. 184-186. 
On January 22, 1820, Artigas was badly defeated by the Portuguese at Tacuarembó and was forced to flee with his shattered army to Entre Ríos. ${ }^{64}$ Shortly thereafter, his one remaining lieutenant, Fructuoso Rivera, was surprised at Tres Árboles and was forced to surrender. Just at this time, however, Pueyrredón and the central government in Buenos Aires fell before the aggressiveness of the federalist caudillos of Entre Ríos and Santa $\mathrm{Fe}$, and Artigas felt new hope. But apparently everything was now working against the Uruguayan.

Sarratea, Artigas' old enemy, became the successor of Pueyrredón, and he made peace with the provincial caudillos on their terms in the Treaty of Pilar on February 23, 1820. Signatory were Sarratea, Estanislao López, and Francisco Ramírez. The treaty provided for an alliance with Artigas against the Portuguese, but Sarratea persuaded Ramirez, with the help of money, that their interests could best be served by eliminating Artigas. The Entre Ríos caudillo turned on his old master. At the time, Artigas was in Abalos, Corrientes, awaiting the aid he had requested from Ramírez. Correspondence between them became acrimonious, a break occurred, and war resulted. In their first clash at Gauchas, in June, 1820, Artigas and his Indian followers won a victory. Reinforced from Buenos Aires, Ramírez met him again at Sauce de Luna, defeating him. From there, the turncoat pursued Artigas and overwhelmed him at Las Tunas, Yuqueri and, finally, at Abalos. ${ }^{65}$

With very few followers, the Uruguayan crossed the Paraná, the border of Paraguay, and there he requested that Dictator Francia grant him asylum. There are many stories told of events that occurred on this final march. It is alleged that two Indian chiefs from the Chaco offered Artigas their men in order that he might continue the fight against Ramírez, and that he refused their aid. Similarly, it is recounted that he rejected an offer of refuge in the United States, tendered him by the consul of that nation in Montevideo. Finally, he is said to have given all his remaining money, some four thousand pesos, to Francisco de los Santos, who carried it to Rio de Janeiro, where it was to be used to help those of his former

64 For a detailed account of the campaign in the Banda Oriental, see Zorrilla de San Martín, op. cit., II, pp. 154-279.

65 Ibid., II, pp. 284-295. Levene, op. cit., p. 344. Lasplaces, op. cit., pp. 194-198. 
lieutenants who were held captive in that place. ${ }^{68}$ Perhaps these stories are apocryphal, but somehow one hopes that they are true.

Francia granted Artigas the asylum he had requested, and on September 23, 1820, the Protector of Free Peoples, the Chief of the Orientales, passed from the brilliance of the field of battle to the obscurity that was Paraguay. The Dictator interned him briefly, perhaps from habit, but soon gave him a small home at Curuguatí, and granted him a modest pension. Revered by his neighbors, Artigas lived in Paraguay in retirement until he died on September 23, 1850, at the age of $86^{67}$

What may be said in evaluating the life and accomplishments of this man? As has been pointed out, those whose judgment of him has been conditioned by reason of nationality have painted him either white or black. But what of the opinions of those who are not thus compelled, those we may safely regard as impartial? .Koebel has said, "Indeed, there is no reason to believe that Artigas, for all his errors and limitations, was not a true believer in the very lofty sentiments he used to express." ${ }^{\text {"68 }}$ An agent of the United States in the Plata region in 1820 reported to the Secretary of State,

That he may have committed outrages I will believe, that he has his peculiarities I well know but he has been uniform in sustaining the Independence of his country and has exhibited an adherence to principle under every specie of privation, that will exalt him in the page of history. ${ }^{69}$

Finally, a French historian, writing quite recently, has said,

Few figures of South American history - and even of the history of humanity - have been more discussed than that of José Artigas. The majority of his contemporary biographies have infused into the spirit of the people of the New World the image of a cruel and perfidious bandit, devoured by the ambition to dominate; others, through an error of historical perspective, accuse him of having been all his life a rebel against the sentiment of national unity. But when, long after his death, the annals of the Wars of Independence are written, the historians who observe, control and register the facts,

66 Zorrilla de San Martín, op. cit., II, pp. 297-300.

67 Bealer, op. cit., p. 57.

68 Koebel, op. cit., p. 91.

69 Manning, op. cit., John B. Prevost to John Quincy Adams, March 9, 1820, I, pp. 543-544, Doc. 252. 
free of all preference and of all the tendencies of imagination, will find, unexpectedly, the revelation of a superior man, gifted with a rectitude each time more inflexible, with a judgment frank and pure, with a firmness of soul and of principles which would have been the pride of the heroes of antiquity. ${ }^{70}$

\section{BIBLIOGRAPHY}

\section{BIBLIOGRAPHIES}

Bealer, Lewis W. "Contribution to a Bibliography on Artigas and the Beginnings of Uruguay, 1810-1820," in The Hispanic American Historical Review, Vol. XI, pp. 109-134, Durham, N. C., Duke University Press, 1931.

\section{PRINTED DoCuments}

Arcbivo General de la Nación. "Acuerdos del Cabildo de Montevideo, Libros XIV y XV, del 12 de Febrero de 1814 al 16 de Marzo de 1816." Montevideo, 1934.

Documentos del Archivo de Pueyrredón 4 Vols. Buenos Aires, Imprenta de Coni Hermanos, 1912.

Documentos Para la Historia Argentina. Vol. VIII, "Sesiones de la Junta Electoral de Buenos Aires, (1815-1820)." Buenos Aires, Compañia SudAmericana de Billetes de Banco, 1917.

Maeso, Justo. Los Primeros Patriotas Orientales de 1811. Montevideo, El Laurak-Bat, 1888.

Manning, William R. Diplomatic Correspondence of the United States Concerning the Independence of the Latin-American Nations. 3 vols. New York, Oxford University Press, 1925.

\section{GENERAL Histories}

Báez, Cecilio. Historia Colonial del Paraguay y Rio de la Plata. Asunción, Imprenta Zamphiropolos y Cía., 1926.

Calogeras, João Pandia. A History of Brazil. Translated and edited by Percy Alvin Martin. Chapel Hill, University of North Carolina Press, 1939.

Koebel, W. H. Uruguay. London, T. Fisher Unwin, 1919.

Levene, Ricardo. A History of Argentina. William Spence Robertson (Ed. \& Transl.). Chapel Hill, University of North Carolina Press, 1937.

López, Vicente F. Historia de la República Argentina. 10 vols. Buenos Aires. Juan Roldán y C. a, 1926.

Mitre, Bartolomé. Historia de Belgano y de la Independencia Argentina. 3 vols. 3rd. Edition. Buenos Aires, Imprenta y Librería de Mayo, de C. Casavalle, 1876-1877.

Pascual, A. D. de. Apuntes para la Historia de la República Oriental del Uruguay. 2 vols. Paris, Imprenta de Bonaventure y Ducessois, 1864.

Salgado, José. Evolución del Pueblo Uruguayo. Montevideo, Imprenta Nacional, 1941.

${ }^{70}$ La Prensa, Buenos Aires, December 11, 1932, Supplement, p. 6. 


\section{SPECIAL WORKS}

Acevedo Díaz, Eduardo. El Mito Del Plata. No publ., no date.

Barbagelata, Lorenzo. Artigas antes de 1810. Montevideo, Impresora Moderna, 1945.

Bealer, Lewis W. "Artigas, the Father of Federalism in La Plata.", in South American Dictators, (A. Curtis Wilgus, ed.). Washington, D. C., The George Washington University Press, 1937.

Blanco Acevedo, Pablo. El Federalismo de Artigas y la Independencia Nacional. Montevideo, Impresora Uruguaya, 1939.

Gandía, Enrique de. Los Treinte y Tres Orientales y la Independencia del Uruguay. Buenos Aires, Espasa-Calpe, 1939.

Lasplaces, Alberto. José Artigas, Protector de los Pueblos Libres. Madrid. Espasa Calpe, 1933.

Garzón, Ignacio. Crónica de Córdoba. 3 vols. La Minerva, 1898-1902.

López, Vicente Fidel. Manual de la Historia Argentina. Buenos Aires, Vacearo, 1920.

Zorrilla de San Martín, Juan. La Epopeya de Artigas. 2 vols. Montevideo, A. Barreiro Y Ramos, 1910.

\section{ARTICLES IN PeRIOdicals}

Martin, Percy Alvin. "Artigas, the Founder of Uruguayan Nationality," in The Hispanic American Historical Review, Vol. XIX, pp. 2-15, Durham, N. C., Duke University Press, 1939.

\section{Periodicals}

Revista de la Biblioteca Nacional. 11 vols. to 1944. Buenos Aires, Imprenta de la Biblioteca Nacional, 1937-19-.

University of California

Bernard F. BobB

Los Angeles, Cal. 